Proceedings of the 10th International Ruminant Reproduction Symposium (IRRS 2018); Foz do Iguaçu, PR, Brazil, September 16th to 20th, 2018.

\title{
Looking at the big picture: understanding how the oviduct's dialogue with gametes and the embryo shapes reproductive success
}

\author{
Beatriz Fernandez-Fuertes ${ }^{1}$, Beatriz Rodríguez-Alonso ${ }^{1,2}$, José María Sánchez ${ }^{1}$, Constantine A. Simintiras ${ }^{1}$, \\ Patrick Lonergan ${ }^{1}$, Dimitrios Rizos ${ }^{2, *}$ \\ ${ }^{1}$ School of Agriculture and Food Science, University College Dublin, Belfield, Ireland. \\ ${ }^{2}$ Departamento de Reproducción Animal, Instituto Nacional de Investigaciones y Tecnologia Agrarias y Alimentarias, \\ Madrid, Spain.
}

\begin{abstract}
The oviduct is a tubular organ comprising three distinct anatomical regions (the infundibulum, the ampulla and the isthmus) connecting the ovary and the uterus. Oviductal function is regulated by ovarian hormones, gametes, and embryo-derived factors, for optimally facilitating key reproductive events. A crosstalk is established between the oviduct and the gametes and embryo and this dialogue shapes the microenvironment in which gamete transport, fertilization, and early embryonic development occur. This review aims to address each participant in this conversation in a holistic manner by delineating several advances in the field within the greater context of understanding how oviduct-gamete and oviduct-embryo dialogue shape reproductive success and furthermore how this knowledge can be applied in vitro.
\end{abstract}

Keywords: cattle, embryo, gametes, interaction, oviduct.

\section{Introduction}

Successful blastocyst production following in vitro fertilization (IVF) and embryo culture (Gordon, 2003), coupled with the fact that pregnancies can be achieved after IVF embryo transfer to non-mated synchronized recipients (Lonergan et al., 2016), indicate that oviduct exposure is not essential for early embryo development. Thus, this has led to the view that the oviduct is a passive conduit for gametes and the early embryo(s). However, a significant body of evidence demonstrates that the oviduct is a dynamic organ. The luminal microenvironment is influenced by ovarian hormones, gametes, and embryo-derived factors, for the purpose of optimally facilitating key reproductive events - to the extent that a pathophysiological peri-conceptual milieu can result in embryo loss, or even adverse lifelong effects (Fazeli, 2008).

Following ovulation and/or insemination, a cross-talk is established between the oviduct and the gametes and embryo. This dialogue will shape the microenvironment in which gamete transport, fertilization, and, if successful fertilization takes place, early embryonic development occur. Studying each conversation participant in isolation facilitates research; however, to fully understand complex oviduct dynamics, a more holistic view is necessary. This review aims to achieve this by delineating several advances in the field within the greater context of understanding how oviduct-gamete and oviduct-embryo dialogue shape reproductive success.

\section{Oviduct anatomy and physiology: epithelial and fluid cyclic changes}

The oviduct is a tubular organ comprising three distinct anatomical regions: 1) the infundibulum, 2) the ampulla, and 3) the isthmus, adjoining the uterus at the utero-tubal junction (UTJ) - all with different, yet equally critical, roles.

The oviduct epithelium comprises secretory (most abundant in the isthmus) and ciliated cells (most abundant in the infundibulum and ampulla; Yániz et al., 2000). The cause of the regional variation in cell type distribution is unknown; however, both lineages derive from embryonically-labelled PAX8+ (a secretory cell marker) cells (Ghosh et al., 2017). Therefore, secretory cells are the oviduct epithelium progenitors, with the potential to self-renew or differentiate into ciliated cells upon 17ß-oestradiol (E2) stimulation (Comer et al., 1998).

The ampullar and the infundibular epithelium undergoes cycle-dependent changes - surface fold amplitude, cell populations, gene expression, and overall physiology vary in response to ovarian steroid fluctuations (Yániz et al., 2000; Cerny et al., 2015). Interestingly, the isthmic epithelium undergoes few changes throughout the cycle (Yániz et al., 2000), despite estrogen receptor alpha $(\mathrm{ER} \alpha)$ and progesterone receptors $\mathrm{A}$ and $\mathrm{B}$ (PRA and $\mathrm{PRB}$ ) being more abundant in the isthmus than the ampulla and infundibulum (Okada et al., 2003). This suggests that the regionspecific differences are not only due to differences in epithelial gene expression, but also likely due to the level of exposure to locally secreted factors specifically from the ovary, ovulated follicle and consequent corpus luteum, via the ovarian artery and the oviductal ostium. This counter-current transfer is thought to underpin oviduct endocrine regulation (Hunter, 2012), and could explain why the ipsilateral oviduct contains higher concentrations of P4 during the luteal phase, relative to its contralateral counterpart (Wijayagunawardane et al., 1998; Lamy et al., 2016). It is important to note, however, that there is conflicting evidence regarding differences in abundance of other hormones such as E2, between ipsilateral and 
contralateral regions (Wijayagunawardane et al., 1998; Lamy et al., 2016). This local delivery system may act to coordinate oviductal tissue changes in step with the pre-ovulatory maturation of the oocyte within the Graafian follicle, and the capacitation of sperm. During the follicular phase, infundibular and ampullar folds reach maximum amplitude (greatest surface area to volume ratio) and exhibit numerous ciliated cells in the apical areas (Yániz et al., 2000), with secretory cells clustered basally, between folds. At this stage, genes involved in cell cycle, cholesterol biosynthesis, cell division, mitosis, and protein folding - responsible for proliferation and secretory activity - are upregulated (Cerny et al., 2015). High E2, characteristic of the preovulatory phase, is thought to be responsible for proliferative epithelial activity (Steffl et al., 2008). Indeed, mitotic activity in the isthmus and ampulla is highest during the follicular phase and around ovulation (Ito et al., 2016). In addition, high E2-low P4 treatment induces morphological changes and increased P4 receptor (PR), estrogen receptor 1 (ESR1), oviductal glycoprotein 1 (OVGP1), and heat shock protein ember $90 \mathrm{kDa}$ member 1 (HSP90B1) gene expression in porcine oviduct cells (Chen et al., 2013). However, in vitro studies reported no increase in proliferation after FSH, LH (in baboon and mouse), or E2 treatment (in the baboon, mouse, and pig; King et al., 2011; Chen et al., 2013), suggesting that additional factors may participate in epithelial remodelling.

At ovulation, expelled follicular fluid contacts the ipsilateral oviduct (Hansen et al., 1991), inducing increased ciliary beat frequency $(\mathrm{CBF})$, therein aiding oocyte transit to the site of fertilization (Lyons et al., 2006). Ovulation, furthermore, induces double-strand DNA breaks in the oviduct epithelial cells (OEC), and increases epithelial macrophage infiltration (King et al., 2011). Interestingly, these macrophages associate with oviduct epithelia adjacent to the cumulus-oocyte complex (COC), which may be important as they secrete cytokines that could interact with the oocyte and the early embryo (Schäfer-Somi, 2003).

After ovulation, the $\mathrm{P} 4$ rise associated with the luteal stage, results in decreased oviduct mucosal fold amplitude, with secretory cells beginning to dominate the luminal landscape (Abe and Oikawa, 1993; Yániz et al., 2000). Epithelial exposure to elevated P4 leads to cell atrophy, decreased cell height, secretory granule loss, and cell death (Steffl et al., 2008). The oviduct epithelium during the luteal phase is also characterised by a downregulation of genes involved in cell communication, blood vessel development, innate and humoral immune responses, complement activation, and an upregulation of genes involved in focal adhesion formation, cell growth regulation, and fatty acid metabolism, amongst others (Hess et al., 2013). These changes are indicative of an environment required to support semi-allogeneic embryo development.

\section{Oviduct fluid dynamics}

Oviduct fluid (OF) formation is a spatiotemporally dynamic process. The spatial secretory profile is influenced by 1) the secretory cell proportion, which increases longitudinally from infundibulum to isthmus (Leese, 1983), and 2) the secretory mucosal surface area, which decreases as the oviduct tapers toward the UTJ. The most pronounced secretory portion of the oviduct is subject to debate. Whilst secretory cells dominate the isthmic luminal landscape $(\sim 70 \%)$, in contrast to $\sim 50 \%$ in the ampulla (Crow et al., 1994), primary metabolites have been detected in the ampulla at 1.8 times their isthmic concentration - presumably owing to the relative secretory mucosal surface area of the ampulla being $\sim 1.8$ times greater (Leese, 1988). Factoring both surface area and secretory cell population, however, the ampulla has a secretory index of $0.9(0.5 \times 1.8)$ compared to the isthmic $0.7(0.7 \times 1.0)$ (adapted from Abe, 1996). This is physiologically counter-intuitive, given that the embryo migrates through the isthmus following fertilisation at the ampullary-isthmic junction.

In addition to spatial variability, $\mathrm{OF}$ composition and volume vary temporally as a function of the oestrous cycle, mediated by steroid hormones acting on the oviduct both directly and indirectly (Aguilar and Reyley, 2005). This was functionally demonstrated first by Bishop (1956) who ligated anaesthetised rabbit oviducts at the UTJ and vertically cannulated the ostium, measuring pressure as a function of fluid formed. At oestrous, oviducts produced $0.79 \mathrm{ml}$ over $24 \mathrm{~h}$, whereas ovariectomised subjects secreted $0.14 \mathrm{ml}$ over the same period. Importantly, secretion rates were restored in ovariectomised rabbits following exogenous E2 supplementation, and secretion volume and pressure declined during pregnancy. Hugentobler et al. (2008) performed a similar study in heifers by catheterising the exteriorised oviduct during surgery. Whilst secretion rates declined from day $0(1.9 \pm 0.3$ $\mu \mathrm{l} / \mathrm{min} ; \mathrm{n}=7 \pm \mathrm{SEM})$ to day $6(1.2 \pm 0.3 \mu \mathrm{l} / \mathrm{min} ; \mathrm{n}=7 \pm$ SEM), differences were non-significant.

The primary OF formation mechanism is osmotic water transfer secondary to solute transit, the dominant of which is $\mathrm{Cl}^{-}$(Dickens et al., 1993; Leese et al., 2001). $\mathrm{K}^{+}$flux is also likely important for moving water apically (Dickens and Leese, 1994). The fact that oviduct epithelia exhibit an inherently relatively low transepithelial resistance (Leese and Gray, 1985) is indicative that paracellular fluid transport also contributes to OF formation and composition (Simintiras and Sturmey, 2017). It is also worth noting that, under physiological conditions, OF composition is influenced by peritoneal and follicular fluid entry from the abdominal cavity, and uterine fluid (UF; Leese, 1988.

\section{OF composition}

Ions

OF ionic composition is highly conserved across mammals, with $\mathrm{K}+$ consistently elevated relative to plasma levels (Aguilar and Reyley, 2005). In cattle, $\mathrm{K}+$ is highest in $\mathrm{OF}$ at oestrus (Olds and VanDemark, 1957), and in mice, more pregnancies were established 
by IVF when using a culture medium high in $\mathrm{K}+$ (Quinn et al., 1985) - the basis of synthetic oviduct fluid (SOF), now also used for cattle embryo production (Gandhi et al., 2000). Ca2+ is also highest in bovine OF around ovulation and is interestingly more abundant in the isthmus than the ampulla (Grippo et al., 1992). This longitudinal variation is unlike $\mathrm{Mg} 2+$ which does not appear to vary spatially but rather temporally (Grippo et al., 1992). It is also interesting to note that the ionic composition and rate of secretion of bovine OF differs considerably to that of uterine fluid (Hugentobler et al., 2007).

\section{Protein}

The OF protein source is twofold: 1) basal vasculature 'filtration' and 2) epithelial synthesis and secretion (Aguilar and Reyley 2005). OF protein levels are $\sim 10-15 \%$ of that of plasma (Leese, 1988), with serum albumin and serum immunoglobulin $G$ comprising approximately $95 \%$ of this total (Oliphant et al., 1978). Other proteins identified include high-density lipoproteins, secreted during the follicular phase, and presumed to bind sperm membrane cholesterol as part of the capacitation process (Ehrenwald et al., 1990).

Further to spatially-regulated protein secretions, a temporal pattern of protein secretion is evident (Nieder and Macon, 1987; Abe, 1996), as discussed below in the context of the best studied and characterised protein of the oviduct: OVGP1, reported as the major secretory glycoprotein which is synthesized and secreted exclusively by the oviduct (Buhi, 2002). OVGP1 is consistently observed in the ampulla across species and enters the lumen via epithelial secretory granule exocytosis (Avilés et al., 2010). OVGP1 has also been identified in in vitro derived bovine, porcine, and murine oviduct fluid (Chen et al., 2017; Simintiras et al., 2017).

OVGP1 secretion in vivo is cycle-dependent and thus correlates with the aforementioned epithelial differentiation states (Verhage et al., 1988); however, OVGP1 production and secretion patterns differ between species. In the goat it is expressed in the infundibulum and ampulla during the follicular phase (Abe et al., 1995) - i.e. around the time of fertilisation but not at the site of fertilisation, whereas in the rat it is secreted predominantly in the isthmus, where the sperm reservoir is located (Abe, 1996). In the bovine, OVGP1 is found in the isthmus and ampulla, the respective sites of sperm capacitation and fertilisation (Lefebvre et al., 1997) during the follicular phase. Ovine OVGP1 is exclusively produced by the ampulla (Gandolfi et al., 1991), in greatest amounts at oestrus (DeSouza and Murray, 1995).

Advances in proteomic methods (Simintiras and Forde, 2017) such as mass spectrometry, will undoubtedly lead to a clearer picture of the oviduct proteome, based on empirical data as opposed to gene expression extrapolations. For instance, a recent study by Acuña et al. (2017) found almost 5000 genes expressed in the porcine oviduct, of which only $7 \%$ corresponded to secretory proteins, and $11 \%$ to membrane proteins - i.e. products with the potential to directly influence the offspring.

\section{Extracellular vesicles}

An additional new area of research lies in luminal extracellular vesicles (EVs). The term EV encompasses different vesicle types, released by somatic cells, that are present in body fluids, and contain bioactive molecules (i.e. mRNAs, small ncRNAs - such as miRNA, proteins, carbohydrates, and lipids; Raposo and Stoorvogel, 2013). EVs are important for intercellular communication, playing a key role in the regulation of physiological and pathological processes (Thery, 2011). EVs can horizontally transfer mRNAs to other cells, which can then be translated into functional proteins at the new location (Hergenreider et al., 2012). EVs have been identified in vivo in several body fluids including amniotic fluid, urine, and blood (Simpson et al., 2008). Until recently, the study of reproductive EVs in mammals was limited to follicular fluid (Silveira et al., 2012), uterine fluid ( $\mathrm{Ng}$ et al., 2013; Burns et al., 2014), and seminal plasma (SP; Piehl et al., 2013). Burns et al. (2016) demonstrated that EVs emanate from both the conceptus trophectoderm and uterine epithelia, and are involved in intercellular communication between these tissues during pregnancy establishment in sheep. Recent studies from our group showed that EVs obtained from bovine OECs cultures in vitro (Lopera-Vásquez et al., 2016) and from bovine OF (Lopera-Vasquez et al., 2017) substantially improved in vitro produced blastocyst quality, measured in terms of cryotolerance, differentially cell count and mRNA abundance of specific genes. However, it was evidenced that EVs obtained from in vivo and in vitro bovine OECs differ in their protein content, with some proteins known to be involved in reproductive function differently abundant in EVs from in vivo compared to in vitro origin (Almiñana et al., 2017). Thus, oviductal EVs from different origins may differ in their ability to mediate key processes such as sperm-oocyte binding and fertilization; for greater detail see (Pérez-Cerezales et al., 2018).

\section{Oviduct-gamete interactions}

The response of the oviduct to sperm or oocytes differs, but both the male and female gamete induce changes in the oviductal proteome (Georgiou et al., 2005). Oviduct-gamete communication is an intricate dialogue leading to the fine regulation of sequential processes resulting in successful fertilization. The main oviduct-driven events in gamete physiology are detailed below.

\section{Oocyte transportation to the site of fertilization}

At ovulation, the $\mathrm{COC}$ is expelled into the peritoneal cavity and guided through the infundibulum into the ampulla of the oviduct. Once contact is established between the COC and the oviduct 
epithelium, ciliated cells transport the COC to the ampulla. In addition to the OF current created by ciliary beating, COC adhesion to ciliary cells is essential for gamete transport (Lam et al., 2000). Adhesion is mediated by the cumulus cells, as their removal prevents oocyte pick-up, due to the zona pellucida not interacting with the epithelia (Mahi-Brown and Yanagimachi, 1983). The granules and filaments of the cumulus extracellular matrix adhere to the glycocalyx of ciliary crowns at the infundibular ciliary tip (Lam et al., 2000). Ciliary beating weakens this adhesive interaction, such that the COC is never completely released, yet rolls into the ampulla. The importance of ciliary cells in this process is highlighted by the fact that women with Kartagener syndrome, a genetic disorder causing defects in global ciliary action, exhibit impaired fertility (Afzelius and Eliasson, 1983; McComb et al., 1986).

Interestingly, mating induces changes in oviduct ER signalling, which is directly involved in oocyte transport acceleration (Orihuela et al., 2009). This could be a mechanism for ensuring that the oocyte and sperm meet at an appropriate time, and represents an example of how the sperm, oocyte, and oviduct interact to ensure successful fertilization.

\section{Oviduct sperm reservoir formation}

In many mammalian species, sperm bind to the isthmic epithelium to establish a sperm reservoir. Different studies have linked the formation of this storage reservoir to the prevention of polyspermy, or maintenance of sperm motility and fertility until ovulation (Suarez, 2006). Indeed, sperm incubated with OECs are capable of developing hypermotility, and maintain their fertilising capacity for $30 \mathrm{~h}$, in contrast to sperm incubated in isolation (Pollard et al., 1991). In the bovine, sperm-oviduct interactions are mediated by fucose residues present throughout the oviduct during oestrus (Lefebvre et al., 1997). Only uncapacitated sperm can bind to the oviduct (Lefebvre and Suarez, 1996). In fact, $\mathrm{Ca} 2+$ influx and tyrosine phosphorylation in sperm are reduced or inhibited whilst bound, likely keeping them uncapacitated (Töpfer-Petersen et al., 2002). Reservoir release likely occurs via plasma membrane modification, leading to the loss of oviductal binding proteins, and hyperactivation of motility (Suarez, 2006). The signals that maintain sperm quiescence and that activate capacitation remain unknown; however, it is plausible that ovarian cues from the dominant or ovulated follicle stimulate the oviduct epithelium to secrete factors that regulate sperm physiology. This would explain why OF from oestrus cows is more successful in inducing sperm capacitation than fluid collected from other stages of the cycle (Parrish et al., 1989).

Once sperm disengage from the reservoir they still have to make their way to the site of fertilisation. So far, four mechanisms have been proposed to guide sperm to the proximity of the oocyte, all of which are driven by the female environment: peristaltic pumping, thermotaxis, rheotaxis, and chemoattractant gradient (Suarez, 2006). The smooth muscle contractions of the oviduct, especially in the isthmus, not only propel sperm, but also create OF currents (Ishikawa et al., 2016). Bull sperm have been shown to orientate their heads against a current when flow velocity reaches 15 $\mu \mathrm{m} / \mathrm{s}$ (Tung et al., 2015). While the rate of fluid flow in the bovine oviduct is unknown, in mice it is $18 \pm 1.6$ $\mu \mathrm{m} / \mathrm{s}$ (Miki and Clapham, 2013). In addition to OF flow, thermotaxis has been proposed as a long-range guiding mechanism. In pigs and rabbits, a temperature drop in the isthmus is observed at ovulation (Hunter and Nichol, 1986; Bahat et al., 2005). Capacitated sperm seem able to sense temperature differences and orientate their swimming towards warmer temperatures (Bahat et al., 2012; Pérez-Cerezales et al., 2015a), leading them to the site of fertilisation. The final guidance system, chemotaxis, is likely limited to short distances, within the order of millimetres (Pérez-Cerezales et al., 2015b). Many substances have been proposed as sperm chemoattractants (reviewed by Eisenbach and Giojalas, 2006); however, due to multiple technical difficulties in chemotactic studies, the data are inconclusive.

\section{Sperm capacitation and hyperactivation}

The fertilising ability of sperm is suppressed until capacitation, a process comprising physiological changes, which physiologically occurs in the female reproductive tract (Yanagimachi, 1994). These include: flagellar motility hyperactivation, regulation of signal transduction pathways enabling chemoattractant responsiveness and acrosome-oocyte reactivity (Florman and Fisore, 2014).

Capacitation seems to be initiated by cholesterol efflux (Visconti et al., 2002). Cholesterol removal requires extracellular bicarbonate and cholesterol acceptors, such as albumin, one of the major OF proteins (Flesch et al., 2001). Cholesterol extraction increases membrane fluidity and ion permeability (Flesch and Gadella, 2000; Khorasani et al., 2000, and initiates diffusion, and possibly formation, of acrosomal lipid raft-like structures containing ZP-binding molecules (Khalil et al., 2006).

In addition to membrane architecture changes, the oviduct can alter sperm motility patterns which can be recapitulated in vitro. Hyperactivated motility, seen in most sperm recovered from the ampulla, requires elevated Ca2+ (Colás et al., 2010) and enables sperm to penetrate $\mathrm{OF}$, the cumulus intercellular matrix, and the ZP. Plasma membrane Ca2+-ATPase 4a (PMCA4a), the major $\mathrm{Ca} 2+$ efflux pump in murine sperm, is present in OF EVs (Al-Dossary et al., 2013), and plays an important role in sperm motility, as its absence leads to an inability to hyperactivate (Okunade et al., 2004). EV PMCA4a is enzymatically active and can be transferred to sperm, as evidenced by increased activity following EV interaction (Bathala et al., 2018). On the other hand, CatSper (cation channel of sperm is the major $\mathrm{Ca} 2+$ entry pathway controlling sperm hyperactivation in different mammalian species (Ren et al., 2001; Quill et al., 2003; Johnson et al., 2017). Nanomolar concentrations of $\mathrm{P} 4$, diluted $\mathrm{ZP}$ preparations, or bovine serum albumin (BSA) can activate CatSper, inducing 
increased intracellular Ca2+ (Xia and Ren, 2009a, b; Lishko et al., 2011; Smith et al., 2013). Therefore, the emerging theory is that CatSper is essential for sperm hyperactivation and is controlled by oviduct signals, depending on sperm location and phase of the cycle (Kirichok and Lishko, 2011; Johnson et al., 2017).

\section{Fertilization}

Soon after the oocyte and sperm meet in the ampulla, fertilization occurs - a complex process requiring an intimate association between the gametes, such that the sperm can penetrate the ZP and plasma membrane, and deliver the paternal DNA. Although some of the key players of these interactions remain unknown, several OF-derived factors are thought to be involved. Perhaps one of the most studied is OVGP1. As mentioned above, OVGP1 has been identified in the OF of numerous mammals, and has been shown to bind to the ZP (O'Day-Bowman et al., 1996; Coy et al., 2008). Interestingly, the role of this protein appears to differ between species. Porcine and bovine oocyte incubation with OF leads to decreased sperm bound to the ZP (Coy et al., 2008). Moreover, in the same species, OF-derived OVGP1 and heparin-like glycosaminoglycans seem to increase ZP resistance to enzymatic digestion and sperm penetration, contributing to the control of polyspermy (Coy et al., 2008; Algarra et al., 2016). OVGP1 can also bind to sperm to mediate changes involved in the process of capacitation and acrosome reaction (Choudhary et al., 2017); another example of how the oviduct can synchronise the capacitation status of the sperm to ensure that fertilization occurs under optimal circumstances.

\section{Immune response modulation}

The immune system of the reproductive tract is uniquely required to protect the mother against pathogens, whilst allowing symbiosis with allogeneic sperm and the semi-allogeneic embryo and fetus. The mechanisms regulating immunological tolerance towards paternal antigens and the embryo have not been completely elucidated. However, the oviduct epithelium seems to play an important role. Sperm incubation with OEC-conditioned media decreases their phagocytosis by neutrophils in vitro (Marey et al., 2014). Prostaglandin E2 (PGE2), alpha-1 acid glycoprotein (AGP), (BSA), and the combination of AGP or BSA with other OF components are predicted to regulate this decreased phagocytosis (Kowsar et al., 2017). It seems that live sperm are involved in the regulation of this protective response, as sperm binding to OECs induces them to produce PGE2, and the anti-inflammatory cytokines TGFB1 and IL10 (Yousef et al., 2016). In contrast, dead or abnormal sperm fail to induce PGE2 secretion (Kodithuwakku et al., 2007).
The role of SP in modulating reproductive immune responses has been gaining interest lately. The absence of SP at insemination in mice leads to decreased embryo development in the oviduct, embryo implantation, and placental development (Bromfield et al., 2014). The positive effect of SP is thought to be attributable to its immunoregulatory properties - it induces antigen specific Treg cell expansion, as well as tolerogenic dendritic cell expansion, considered important in immune tolerance to paternal antigens in the embryo (Robertson et al., 2009; Guerin et al., 2011; Shima et al., 2015). In addition, granulocytemacrophage colony-stimulating factor (CSF2), leukemia inhibitory factor (LIF), interleukin 6 (IL6), and tumor necrosis factor-related apoptosis-inducing ligand (TRAIL), embryokines important to embryo quality, can be regulated by SP exposure in the oviduct (Bromfield, 2016). Thus, seminal plasma may help shape an optimal environment for the early embryo. However, evidence for a significant role for seminal plasma in pregnancy establishment in cattle is not clear. To date, the only study that has looked at the effect of SP or transforming growth factor beta (TGF $\beta$ ) (thought to be responsible for the beneficial effects of SP in rodents) in cattle pregnancy outcome, concluded that this factor (but not SP as a whole) had a positive effect only when reproduction was suboptimal (Odhiambo et al., 2009).

\section{Oviduct-embryo communication}

Following fertilization, the bovine zygote spends $\sim 4$ days in the oviduct until migrating to the uterus as a 16-cell stage embryo (Hunter, 2012). During this period, the oviduct provides a nourishing environment conducive to embryo development comprising simple and complex carbohydrates, ions, lipids, phospholipids and proteins (Avilés et al., 2010). In addition, the oviduct is also responsible of transporting the embryo to the uterus through muscular and ciliary activity.

Whilst uterine-embryo dialogue has been extensively studied, relatively little is still known about oviduct-embryo communication. Our current understanding is that this phenomenon is a two-way process (Fig. 1), i.e. signals can be sent and received from both the oviduct and the embryo; however, these remain largely undefined. Our group has recently described bone morphogenetic proteins (BMPs) as participants in a signalling pathway involved in oviductembryo cross-talk in vitro (García et al., 2017). Embryooviduct interaction in vitro induces transcriptional changes of BMP signalling components, both through direct and indirect contact (Hamdi et al., 2018), indicating that the signal is released in OF. Thus, analysing early embryo-maternal interactions involves studying $\mathrm{OF}$ in addition to the embryo, oviduct epithelium, and the direction of the communication. 

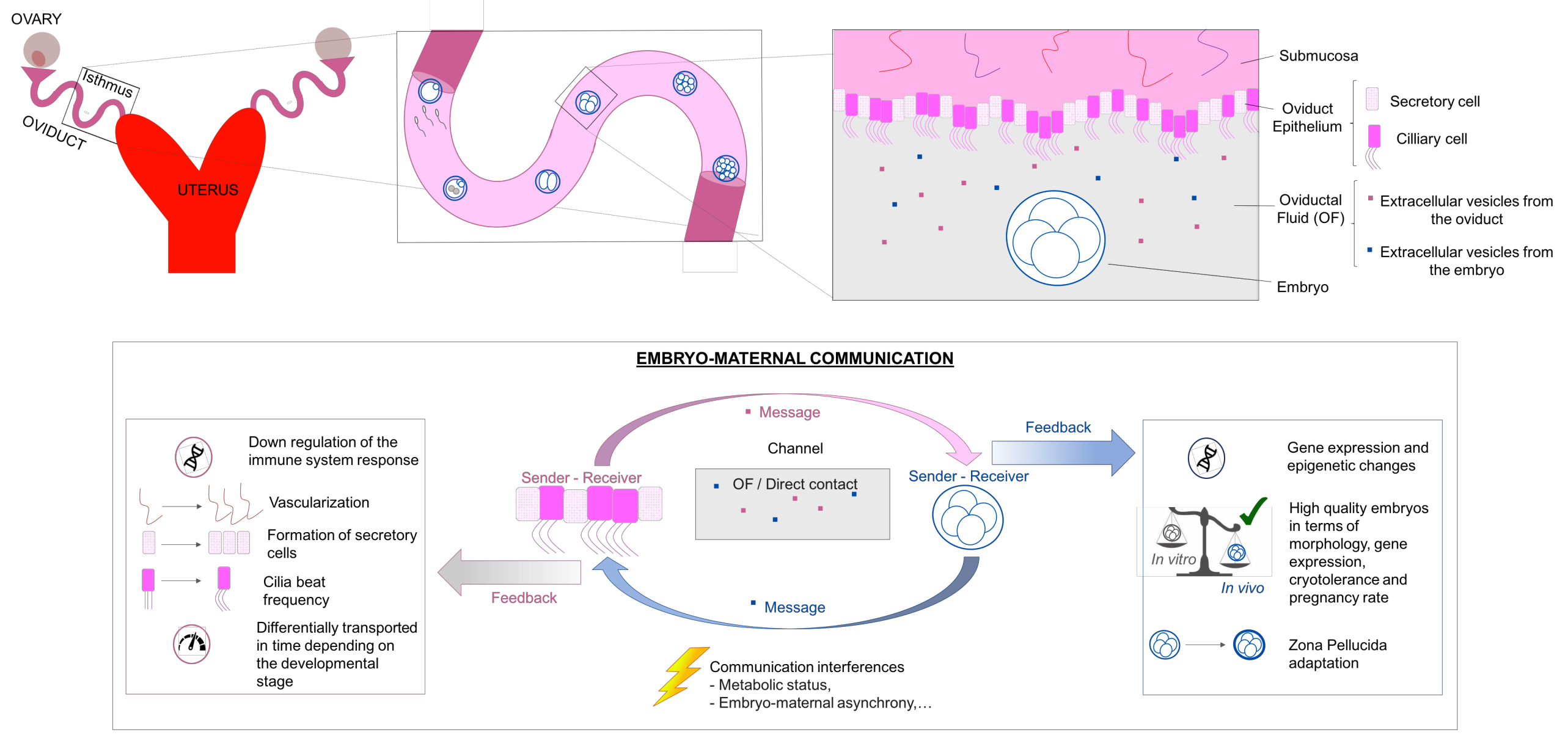

Figure 1. Schematic representation of embryo-maternal communication in the oviduct. 
In vivo modelling

Although tremendous advances have led to improved in vitro models for studying embryo-oviduct interactions, such models remain limited in their ability to fully mimic in vivo conditions (Lonergan and Fair, 2008). Therefore, animal models are crucial to holistically understanding the physiology and pathology surrounding early embryo development.

In our laboratory, we have investigated the effect of different embryo culture environments (in vitro, in vivo in surrogate ovine oviducts, and ex vivo in the murine oviduct) on blastocyst development and quality, finding that culture in the oviduct (in vivo and ex vivo) improves embryo quality in terms of morphology, gene expression, and cryotolerance (Enright et al., 2000; Rizos et al., 2002; Lonergan et al., 2003). Interestingly, heterologous embryo culture can support early embryo development, resulting in the establishment and maintenance of pregnancy, although only the ovine oviduct has been routinely used for bovine embryo culture (Lazzari et al., 2010). A new approach for culturing in vitro and/or in vivo produced embryos in the homologous bovine oviduct in vivo by transvaginal endoscopy has been introduced successfully (Besenfelder et al., 2010). Using this technique, Wetscher et al. (2005) and Havlicek et al. (2010), found that short and long-term in vivo culture of in vitro produced embryos in the homologous bovine oviduct enhanced blastocyst quality, in terms of cryotolerance, relative to blastocysts grown entirely in vitro. Moreover, total blastocyst yields were similar to previous data derived using surrogated heterologous oviducts as a temporary incubator (Enright et al., 2000, Rizos et al., 2002; Lonergan et al., 2003; Lazzari et al., 2010).

A key milestone in early embryo development is embryonic genome activation (EGA). Using alternative in vivo and in vitro culture conditions for blastocyst production, Gad et al. (2012) demonstrated that in vitro conditions at the time of major EGA critically influence the transcriptome of the subsequent blastocysts. Furthermore, the methylation pattern of in vitro derived blastocysts differs from in vivo counterparts (Gad et al., 2012). This was demonstrated in the bovine by Salilew-Wondim et al. (2015), who transferred in vitro zygotes, 4-cell, and 16-cell embryos into recipient heifer oviducts. Resulting blastocysts were recovered on day 7 and compared with blastocysts produced in vitro. The degree of DNA methylation dysregulation in the promoter and/or gene body regions was correlated positively with in vitro culture duration.

Due to the early embryo being usually described as somewhat autonomous up to the blastocyst stage (i.e. does not need contact with the maternal reproductive tract), one could argue about the influence of maternal-embryonic asynchrony on embryo development. To investigate this further, our group endoscopically transferred day 1 in vitro produced bovine zygotes to the oviducts of heifers either synchronous with the embryos (at day 1 post-ovulation), or asynchronous (at day 3 post-ovulation), prior to embryo recovery on day 4 (8- to 16-cell stage), day 7 (morula-blastocyst), and day 15 (elongated conceptus). Interestingly, asynchrony had a negative impact on early embryo survival and development (Rodríguez-Alonso et al., 2018a), unlike in the uterus, wherein the transfer of a blastocyst to an advanced uterus results in accelerated embryo development (Randi et al., 2016).

Another study from our group assessed the contribution of the oviduct to poor fertility in postpartum dairy cows - a disorder linked with suboptimal follicle development, oocyte quality, sperm transport and fertilization, reproductive tract environment, and/or a combination of these (Lonergan et al., 2016) - and found significantly lower blastocyst yields when in vitro produced zygotes were transferred to the oviducts of lactating ( day 60 postpartum $v s$. dry cows (Maillo et al., 2012) and heifers (Rizos et al., 2010).

Today, most of the studies related to the maternal-embryo interactions in the oviduct reflect the effect on the embryo, meanwhile there are only few reported the converse effect on the oviduct (reviewed by Maillo et al., 2016). Even more, most of them have been performed in poly-ovulatory species $-e . g$. murine and porcine - in which the presence of multiple embryos presumably magnifies the signal for altering OEC gene expression (Chang et al., 2000; Lee et al., 2002; Almiñana et al., 2012). In an effort to dissect the directionality of oviduct-embryo dialogue in the monoovulatory species, Smits et al. (2016) reported a local influence of a single embryo on the transcriptome of the equine oviduct epithelium; while in bovine Maillo et al., (2015) was unable to detect differences in the oviduct isthmus transcriptome in the presence of a single embryo. However, when up to 50 embryos were endoscopically transferred into heifer oviducts, with the aim of amplifying embryo-derived signals, OEC transcriptomic differences became apparent, mostly related to the immune system response. Thus, the physiological local embryo-oviduct interaction may be undetectable using current technologies owing to the relatively small and localised response elicited.

To tease this out, we recently isolated ipsilateral oviducts from single-ovulated artificially inseminated heifers post-mortem on day 2.5 post-estrus. These were subsequently sectioned (into $2 \mathrm{~cm}$ lengths) and flushed for embryo retrieval (2-cell). The expression of 10 genes previously shown to be differentially expressed between the isthmus of pregnant and cyclic heifers (Maillo et al., 2015), was assessed. Differences were found both where the embryo was located and proximally, i.e. where the embryo had passed (Rodríguez-Alonso et al., 2018b).

\section{In vitro modelling}

Owing to technical limitations surrounding OF sampling in vivo (see Leese et al., 2008) coupled with logistical issues, and the high costs associated with in vivo studies, in vitro models are pivotal to studying oviduct physiology. In vitro modelling furthermore enables investigations of greater environmental 
manipulation, (Ulbrich et al., 2010). OECs are currently generally cultured in vitro as basic monolayers or cell suspensions (Lopera-Vásquez et al. 2016), polarized two-dimensional monolayers (Chen et al., 2017; Jordaens et al., 2017; Simintiras et al., 2017), or threedimensional monolayers (Ferraz et al., 2017a, b).

Despite in vitro OEC de-differentiation and morphological characteristic loss (Rottmayer, et al. 2006), including height reduction, cilia and secretory granule loss, and bulbous protrusions (Thibodeaux, et al. 1992, Walter 1995), in vitro modelling presents an opportunity to detect essential and functional candidate genes in embryo-maternal dialogue (Schmaltz-Panneau et al. 2014) that are difficult to study in vivo, and the capacity to investigate OF formation and regulation free from systemic effects (Simintiras et al., 2017). The latter, coupled with OEC-conditioned media (RamosIbeas et al. 2014), offer scope for improving in vitro embryo culture, particularly as co-culture is associated with a lack of reproducibility, biosanitary risk (Guerin et al. 1997), do not contain foreign cells, and contain embryotrophic factors (Ramos-Ibeas et al., 2014). We recently reported that conditioned media from extended bovine OEC monolayer cultures had a consistently positive effect on blastocyst quality when used during IVC (Lopera-Vásquez et al. 2016).

One limitation of in vitro work is an inherent behavioural variability between cell populations; however, a promising solution is the use of immortalised cell lines that maintain many primary culture attributes (Ulbrich et al. 2010). Another development is the short-term $(24 \mathrm{~h})$ epithelial cell suspension culture, in which OECs maintain morphological characteristics as well as gene markers present in vivo such as OVGP1, E2 and P4 receptors (Rottmayer, et al. 2006). However, suspended cells do not adhere and mitosis does not occur (Walter, 1995).

The OEC polarized system consists of culturing the cells on inserts to allow media access from both basolateral (vasculature mimic) and apical (luminal mimic) sides, therein also maintaining the natural asymmetrical nature of the epithelium. This system preserves detailed morphological features of the porcine oviduct and oviduct-specific markers (Miessen et al., 2011). Bovine OECs cultured in this way have been used to model elevated non-esterified fatty acid metabolic stress (Jordaens et al., 2015, 2017) in addition to testing the barrier properties of the oviduct epithelium to dietary-derived embryotoxins (Simintiras and Sturmey, 2017). Another category of such polarized culture is the air-liquid interface (ALI) system in which medium is exclusively supplied basolaterally, allowing the formation of oviduct fluid surrogate or in vitro derived oviduct fluid (Simintiras et al., 2017), in the apical chamber. Epithelia derived from human, porcine, and bovine oviducts maintain polarity and an in vivolike morphology when cultured like this long-term (Chen et al., 2013, 2017; Levanon et al., 2010).

Moreover, Chen et al. (2017) reported that ALI supports development in vitro in the OFC, of porcine, murine, and bovine embryos. However, blastocyst rates were inferior to current optimized standard IVP procedures, suggesting a need for further model improvement by simulating physiological hormonal changes, and developing a sequential culture system using oviduct as well as uterine epithelial cells (Chen $e t$ al., 2017).

Very recently, the use of three-dimensional (3D) printing in combination with microfluidics, has led to the creation of the oviduct-on-a-chip with a U-shaped porous membrane enabling OEC polarization, which can be maintained during long-term culture, therein mimicking tissue and organ-specific micro-architecture (Ferraz et al., 2017a, b). It has also been shown that specific tissue morphology and functions are more faithfully mimicked in customized 3D vs. 2D systems (Gualtieri et al., 2012; Costello et al., 2014).

As aforementioned within an in vivo context, in vitro derived embryos also secrete EVs (Saadeldin et al., 2015). These data led us to hypothesize that culture medium supplementation with OEC EVs could initiate a maternal-embryo dialogue beneficial to embryo development. We found that suplementation of in vitro embryo culture media with bovine EVs obtained from OECs culture in vitro (Lopera-Vásquez et al., 2016) and in vivo (OF) (Lopera-Vasquez et al., 2017) substantially improved in vitro produced blastocyst quality.

In addition, the use of OF and UF has been recently used to improve in vitro embryo production. One example is a study from our group for which in vitro derived embryos were produced and cultured with or without $\mathrm{OF}$ and/or UF supplemented media. Low concentrations of OF (days 1 to 4 ) and UF (days 4 to 8 ) in serum-free culture indeed supported embryo development and improved embryo quality with OF incorporation resulted in more physiological embryo methylation patterns, whereas UF is thought to have played an antioxidant role (Hamdi et al., 2017).

In conclusion, the oviduct is an important, unique, and interesting secretory organ gaining greater attention owing to increased awareness of embryoinduced changes affecting later stages of development. Answers to fundamental questions foreseeably reside in merging data obtained from advanced complementary in vivo and in vitro methodologies, all geared at understanding important events of early embryomaternal communication.

\section{Acknowledgments}

The authors' work is supported by the Spanish Ministry of Economy and Competitiveness, AGL201570140-R; EU, Horizon 2020 Marie Sklodowska-Curie, REPBIOTECH 675526, Science Foundation Ireland (13/IA/1983), the Irish Research Council (GOIPD/2017/942), and a University College Dublin Career Development Award (54580). Authors are members of the European Cooperation in Science and Technology, Cost Action CA 16119 - In vitro 3-D total cell guidance and fitness. 


\section{References}

Abe H, Oikawa T. 1993. Observations by scanning electron microscopy of oviductal epithelial cells from cows at follicular and luteal phases. Anat Rec, 235:399410.

Abe H, Sendai Y, Satoh T, Hoshi H. 1995. Bovine oviduct-specific glycoprotein: a potent factor for maintenance of viability and motility of bovine spermatozoa in vitro. Mol Reprod Dev, 42:226-232.

Abe H. 1996. The mammalian oviductal epithelium: regional variations in cytological and functional aspects of the oviductal secretory cells. Histol Histopathol, 11:743-768.

Acuña OS, Avilés M, López-Úbeda R, GuillénMartínez A, Soriano-Úbeda C, Torrecillas A, Coy P, Izquierdo-Rico MJ. 2017. Differential gene expression in porcine oviduct during the oestrous cycle. Reprod Fertil Dev, 29:2387-2399.

Afzelius BA, Eliasson R. 1983. Male and female infertility problems in the immotile-cilia syndrome. Eur J Respir Dis Suppl, 127:144-147.

Aguilar J, Reyley M. 2005. The uterine tubal fluid: secretion, composition and biological effects. Anim Reprod Sci, 2:91-105.

Al-Dossary AA, Strehler EE, Martin-DeLeon PA. 2013. Expression and secretion of plasma membrane $\mathrm{Ca} 2+-A T P a s e$ 4a (PMCA4a during murine estrus: association with oviductal exosomes and uptake in sperm. PLoS One, 8:e80181. doi: 10.1371/journal. pone. 0080181 .

Algarra B, Han L, Soriano-Úbeda C, Avilés M, Coy P, Jovine L, Jiménez-Movilla M. 2016. The Cterminal region of OVGP1 remodels the zona pellucida and modifies fertility parameters. Sci Rep, 6:32556. doi: $10.1038 /$ srep32556.

Almiñana C, Heath PR, Wilkinson S, SanchezOsorio J, Cuello C, Parrilla I, Gil MA, Vazquez JL, Vazquez JM, Roca J, Martinez EA, Fazeli A. 2012. Early developing pig embryos mediate their own environment in the maternal tract. PLoS One, 7:e33625. doi: 10.1371/journal.pone.0033625.

Almiñana C, Corbin E, Tsikis G, Alcântara-Neto AS, Labas V, Reynaud K, Galio L, Uzbekov R, Garanina AS, Druart X, Mermillod P. 2017. Oviduct extracellular vesicles protein content and their role during oviduct-embryo cross-talk. Reproduction, 154:153-168.

Avilés M, Gutiérrez-Adán A, Coy P. 2010. Oviductal secretions: will they be key factors for the future ARTs? Mol Hum Reprod, 16:896-906.

Bahat A, Eisenbach M, Tur-Kaspa I. 2005. Periovulatory increase in temperature difference within the rabbit oviduct. Hum Reprod, 20:2118-2121.

Bahat A, Caplan SR, Eisenbach M. 2012. Thermotaxis of human sperm cells in extraordinarily shallow temperature gradients over a wide range. PLoS One, 7:e41915. doi: 10.1371/journal.pone.0041915.

Bathala P, Fereshteh Z, Li K, Al-Dossary AA, Galileo DS, Martin-DeLeon PA. 2018. Oviductal extracellular vesicles (oviductosomes, OVS are conserved in humans: murine OVS play a pivotal role in sperm capacitation and fertility. Mol Hum Reprod, 24:143-157.

Besenfelder U, Havlicek V, Kuzmany A, Brem G. 2010. Endoscopic approaches to manage in vitro and in vivo embryo development: use of the bovine oviduct. Theriogenology, 73:768-776.

Bishop DW. 1956. Active secretion in the rabbit oviduct. Am J Physiol, 187:347-352.

Bromfield JJ, Schjenken JE, Chin PY, Care AS, Jasper MJ, Robertson SA. 2014. Maternal tract factors contribute to paternal seminal fluid impact on metabolic phenotype in offspring. Proc Natl Acad Sci, 111:22002205.

Bromfield JJ. 2016. A role for seminal plasma in modulating pregnancy outcomes in domestic species. Reproduction, 152:R223-R232.

Buhi WC. 2002. Characterization and biological roles of oviduct-specific, oestrogen-dependent glycoprotein. Reproduction, 123:355-362.

Burns G, Brooks K, Wildung M, Navakanitworakul R, Christenson LK, Spencer TE. 2014. Extracellular vesicles in luminal fluid of the ovine uterus. PloS One, 9:e90913. doi: 10.1371/journal.pone.0090913.

Burns GW, Brooks KE, Spencer TE. 2016. Extracellular vesicles originate from the conceptus and uterus during early pregnancy in sheep. Biol Reprod, 94 . doi: 10.1095/biolreprod.115.134973.

Cerny KL, Garrett E, Walton AJ, Anderson LH, Bridges PJ. 2015. A transcriptomal analysis of bovine oviductal epithelial cells collected during the follicular phase versus the luteal phase of the estrous cycle. Reprod Biol Endocrinol, 13:84. doi: 10.1186/s12958015-0077-1.

Chang H-S, Cheng WTK, Wu H-K, Choo K-B. 2000. Identification of genes expressed in the epithelium of porcine oviduct containing early embryos at various stages of development. Mol Reprod Dev, 56:331-335.

Chen S, Einspanier R, Schoen J. 2013. In vitro mimicking of estrous cycle stages in porcine oviduct epithelium cells: estradiol and progesterone regulate differentiation, gene expression, and cellular function. Biol Reprod, 89. doi: 10.1095/biolreprod.113.108829.

Chen S, Palma-Vera SE, Langhammer M, Galuska SP, Braun BC, Krause E, Lucas-Hahn A, Schoen J. 2017. An air-liquid interphase approach for modeling the early embryo-maternal contact zone. Sci Rep, 7:42298. doi: 10.1038/srep42298.

Choudhary S, Kumaresan A, Kumar M, Chhillar S, Malik H, Kumar S, Kaushik J.K, Datta TK, Mohanty AK. 2017. Effect of recombinant and native buffalo OVGP1 on sperm functions and in vitro embryo development: a comparative study. $J$ Anim Sci Biotechnol. 8. doi: 10.1186/s40104-017-0201-5.

Colás C, Cebrián-Pérez JA, Muiño-Blanco T. 2010. Caffeine induces ram sperm hyperactivation independent of cAMP-dependent protein kinase. Int $J$ Androl, 33:e187-e197.

Comer MT, Leese HJ, Southgate J. 1998. Induction of a differentiated ciliated cell phenotype in primary cultures of Fallopian tube epithelium. Hum Reprod, 13:3114-3120.

Costello CM, Hongpeng J, Shaffiey S, Yu J, Jain NK, 
Hackam D, March JC. 2014. Synthetic small intestinal scaffolds for improved studies of intestinal differentiation. Biotechnol Bioeng, 111:1222-1232.

Coy P, Cánovas S, Mondéjar I, Saavedra MD, Romar R, Grullón L, Matás C, Avilés M. 2008. Oviduct-specific glycoprotein and heparin modulate sperm-zona pellucida interaction during fertilization and contribute to the control of polyspermy. Proc Natl Acad Sci USA, 105:15809-15814.

Crow J, Amso NN, Lewin J, Shaw RW. 1994. Morphology and ultrastructure of fallopian tube epithelium at different stages of the menstrual cycle and menopause. Hum Reprod, 9:2224-2233.

DeSouza MM, Murray MK. 1995. An estrogendependent secretory protein, which shares identity with chitinases, is expressed in a temporally and regionally specific manner in the sheep oviduct at the time of fertilization and embryo development. Endocrinology, 136:2485-2496.

Dickens CJ, Southgate J, Leese HJ. 1993. Use of primary cultures of rabbit oviduct epithelial cells to study the ionic basis of tubal fluid formation. $J$ Reprod Fertil, 98:603-610.

Dickens CJ, Leese HJ. 1994. The regulation of rabbit oviduct fluid formation. J Reprod Fertil, 100:577-581.

Ehrenwald E, Foote RH, Parks JE. 1990. Bovine oviductal fluid components and their potential role in sperm cholesterol efflux. Mol Reprod Dev, 25:195-204.

Eisenbach M, Giojalas LC. 2006. Sperm guidance in mammals - an unpaved road to the egg. Nat Rev Mol Cell Biol, 7:276-285.

Enright BP, Lonergan P, Dinnyes A, Fair T, Ward FA, Yang X, Boland MP. 2000. Culture of in vitro produced bovine zygotes in vitro vs in vivo: implications for early embryo development and quality. Theriogenology, 54:659-673.

Fazeli A. 2008. Maternal communication with gametes and embryos. Theriogenology, 70:1182-1187.

Ferraz MAMM, Henning HHW, Costa PF, Malda J, Melchels FP, Wubbolts R, Stout TAE, Vos PLAM, Gadella BM. 2017a. Improved bovine embryo production in an oviduct-on-a-chip system: prevention of poly-spermic fertilization and parthenogenic activation. Lab Chip, 17:905-916.

Ferraz MAMM, Henning HHW, Stout TAE, Vos PLAM, Gadella BM. 2017b. Designing 3-dimensional in vitro oviduct culture systems to study mammalian fertilization and embryo production. Ann Biomed Eng, 45:1731-1744.

Flesch FM, Gadella BM. 2000. Dynamics of the mammalian sperm plasma membrane in the process of fertilization. Biochim Biophys Acta, 1469:197-235.

Flesch FM, Brouwers JFHM, Nievelstein PFEM, Verkleij AJ, van Golde LMG, Colenbrander B, Gadella BM. 2001. Bicarbonate stimulated phospholipid scrambling induces cholesterol redistribution and enables cholesterol depletion in the sperm plasma membrane. J Cell Sci, 114:3543-3555.

Florman HM, Fissore RA. 2014. Fertilization in mammals. In: Plant T, Zeleznik A (Ed.). Knobil and Neill's Physiology of Reproduction. Cambridge, Mass: Academic Press. pp. 149-196.
Gad A, Hoelker M, Besenfelder U, Havlicek V, Cinar U, Rings F, Held E, Dufort I, Sirard M-A, Schellander K, Tesfaye D. 2012. Molecular mechanisms and pathways involved in bovine embryonic genome activation and their regulation by alternative in vivo and in vitro culture conditions. Biol Reprod, 87:100. doi: 10.1095/biolreprod.112.099697.

Gandhi AP, Lane M, Gardner DK, Krisher RL. 2000. A single medium supports development of bovine embryos throughout maturation, fertilization and culture. Hum Reprod, 15:395-401.

Gandolfi F, Modina S, Brevini TA, Galli C, Moor RM, Lauria A. 1991. Oviduct ampullary epithelium contributes a glycoprotein to the zona pellucida, perivitelline space and blastomeres membrane of sheep embryos. Eur J Basic Appl Histochem, 35:383-392.

García EV, Hamdi M, Barrera AD, SánchezCalabuig MJ, Gutiérrez-Adán A, Rizos D. 2017. Bovine embryo-oviduct interaction in vitro reveals an early cross talk mediated by BMP signaling. Reproduction, 153:631-643.

Georgiou AS, Sostaric E, Wong CH, Snijders APL, Wright PC, Moore HD, Fazeli A. 2005. Gametes alter the oviductal secretory proteome. Mol Cell Proteomics, 4:1785-1796

Ghosh A, Syed SM, Tanwar PS. 2017. In vivo genetic cell lineage tracing reveals that oviductal secretory cells self-renew and give rise to ciliated cells. Development, 144;3031-3041.

Gordon I. 2003. Laboratory Production of Cattle Embryos. Wallingford, uk: CABI.

Grippo AA, Henault MA, Anderson SH, Killian GJ. 1992. Cation concentrations in fluid from the oviduct ampulla and isthmus of cows during the estrous cycle. $J$ Dairy Sci, 75:58-65.

Gualtieri R, Mollo V, Braun S, Barbato V, Fiorentino I, Talevi R. 2012. Long-term viability and differentiation of bovine oviductal monolayers: bidimensional versus three-dimensional culture. Theriogenology, 78:1456-1464.

Guerin B, Nibart M, Guienne BM-L, Humblot P. 1997. Sanitary risks related to embryo transfer in domestic species. Theriogenology, 47:33-42. https://doi.org/10.1016/S0093-691X(96)00337-8

Guerin LR, Moldenhauer LM, Prins JR, Bromfield JJ, Hayball JD, Robertson SA. 2011. Seminal fluid regulates accumulation of FOXP3+ regulatory $\mathrm{T}$ cells in the preimplantation mouse uterus through expanding the FOXP3+ cell pool and CCL19-mediated recruitment. Biol Reprod, 85:397-408.

Hamdi M, Lopera-Vasquez R, Maillo V, SanchezCalabuig MJ, Núnez C, Gutierrez-Adan A, Rizos D. 2017. Bovine oviductal and uterine fluid support in vitro embryo development. Reprod Fertil Dev. doi: 10.1071/RD17286.

Hamdi M, Rodríguez-Alonso B, Almansa-Ordonez A, Gutierrez-Adán A, Lonergan P, Rizos D. 2018. 116 In vitro transcriptomic response of bovine oviduct epithelial cells to direct or indirect embryo contact. Reprod Fertil Dev, 30:197-198. (abstract).

Hansen C, Srikandakumar A, Downey BR. 1991. Presence of follicular fluid in the porcine oviduct and its 
contribution to the acrosome reaction. Mol Reprod Dev, 30:148-153.

Havlicek V, Kuzmany A, Cseh S, Brem G, Besenfelder U. 2010. The effect of long-term in vivo culture in bovine oviduct and uterus on the development and cryo-tolerance of in vitro produced bovine embryos. Reprod Domest Anim, 45:832-837.

Hergenreider E, Heydt S, Tréguer K, Boettger T, Horrevoets AJG, Zeiher AM, Scheffer MP, Frangakis AS, Yin X, Mayr M, Braun T, Urbich C, Boon RA, Dimmeler S. 2012. Atheroprotective communication between endothelial cells and smooth muscle cells through miRNAs. Nat Cell Biol, 14:249256

Hess A, Talbi S, Hamilton A, Baston-Buest D, Nyegaard $M$, Irwin $J$, Barragan $F$, Kruessel $\mathbf{J}$, Germeyer A, Giudice L. 2013. The human oviduct transcriptome reveals an anti-inflammatory, antiangiogenic, secretory and matrix-stable environment during embryo transit. Reprod Biomed Online, 27:423435.

Hugentobler SA, Morris DG, Sreenan JM, Diskin MG. 2007. Ion concentrations in oviduct and uterine fluid and blood serum during the estrous cycle in the bovine. Theriogenology, 68:538-548.

Hugentobler SA, Humpherson PG, Leese HJ, Sreenan JM, Morris DG. 2008. Energy substrates in bovine oviduct and uterine fluid and blood plasma during the oestrous cycle. Mol Reprod Dev, 75:496-503. Hunter RHF, Nichol R. 1986. A preovulatory temperature gradient between the isthmus and ampulla of pig oviducts during the phase of sperm storage. $J$ Reprod Fertil, 77:599-606.

Hunter RHF. 2012. Components of oviduct physiology in eutherian mammals. Biol Rev Camb Philos Soc, 87:244-255.

Ishikawa Y, Usui T, Yamashita M, Kanemori Y, Baba T. 2016. Surfing and swimming of ejaculated sperm in the oviduct. Biol Reprod,. 94:89. doi: 10.1095/biolreprod.115.135418.

Ito S, Kobayashi Y, Yamamoto Y, Kimura K, Okuda K. 2016. Remodeling of bovine oviductal epithelium by mitosis of secretory cells. Cell Tissue Res, 366:403-410. Johnson GP, English A-M, Cronin S, Hoey DA, Meade KG, Fair S. 2017. Genomic identification, expression profiling, and functional characterization of CatSper channels in the bovine. Biol Reprod, 97:302312.

Jordaens L, Arias-Alvarez M, Pintelon I, Thys S, Valckx S, Dezhkam Y, Bols PEJ, Leroy JLMR. 2015 Elevated non-esterified fatty acid concentrations hamper bovine oviductal epithelial cell physiology in three different in vitro culture systems. Theriogenology, 84:899-910.

Jordaens L, Van Hoeck V, Maillo V, Gutierrez-Adan A, Marei WFA, Vlaeminck B, Thys S, Sturmey RG, Bols PEJ, Leroy JLMR. 2017. Maternal metabolic stress may affect oviduct gatekeeper function. Reproduction, 153:759-773.

Khalil MB, Chakrabandhu K, Xu H, Weerachatyanukul W, Buhr M, Berger T, Carmona E, Vuong N, Kumarathasan P, Wong PTT, Carrier
D, Tanphaichitr N. 2006. Sperm capacitation induces an increase in lipid rafts having zona pellucida binding ability and containing sulfogalactosylglycerolipid. Dev Biol. 290:220-235.

Khorasani AM, Cheung AP, Lee C-YG. 2000. Cholesterol inhibitory effects on human sperm - induced acrosome reaction. J Androl, 21:586-594.

King SM, Hilliard TS, Wu LY, Jaffe RC, Fazleabas AT, B,rdette JE. 2011. The impact of ovulation on fallopian tube epithelial cells: evaluating three hypotheses connecting ovulation and serous ovarian cancer. Endocr Relat Cancer, 18:627-642.

Kirichok Y, Lishko PV. 2011. Rediscovering sperm ion channels with the patch-clamp technique. Mol Hum Reprod, 17:478-499.

Kodithuwakku SP, Miyamoto A, Wijayagunawardane MPB. 2007. Spermatozoa stimulate prostaglandin synthesis and secretion in bovine oviductal epithelial cells. Reproduction, 133:1087-1094.

Kowsar R, Keshtegar B, Marey MA, Miyamoto A. 2017. An autoregressive logistic model to predict the reciprocal effects of oviductal fluid components on in vitro spermophagy by neutrophils in cattle. Sci Rep, 7:4482. doi: 10.1038/s41598-017-04841-z

Lam X, Gieseke C, Knoll M, Talbot P. 2000. Assay and importance of adhesive interaction between hamster (Mesocricetus auratus oocyte-cumulus complexes and the oviductal epithelium. Biol Reprod, 62:579-588.

Lamy J, Liere $\mathbf{P}$, Pianos A, Aprahamian F, Mermillod P, Saint-Dizier M. 2016. Steroid hormones in bovine oviductal fluid during the estrous cycle. Theriogenology, 86:1409-1420.

Lazzari G, Colleoni S, Lagutina I, Crotti G, Turini P, Tessaro I, Brunetti D, Duchi R, Galli C. 2010. Short-term and long-term effects of embryo culture in the surrogate sheep oviduct versus in vitro culture for different domestic species. Theriogenology, 73:748-757.

Lee K-F, Yao Y-Q, Kwok K-L, Xu J-S, Yeung WSB. 2002. Early developing embryos affect the gene expression patterns in the mouse oviduct. biochem. Biophys Res Commun, 292:564-570.

Leese HJ. 1983. Studies on the movement of glucose, pyruvate and lactate into the ampulla and isthmus of the rabbit oviduct. $Q J$ Exp Physiol, 68:89-96.

Leese HJ, Gray SM. 1985. Vascular perfusion: a novel means of studying oviduct function. Am J Physiol, 248:E624-632.

Leese HJ. 1988. The formation and function of oviduct fluid. J Reprod Fertil, 82:843-856.

Leese HJ, Tay JI, Reischl J, Downing SJ. 2001. Formation of Fallopian tubal fluid: role of a neglected epithelium. Reproduction, 121:339-346.

Leese HJ, Hugentobler SA, Gray SM, Morris DG, Sturmey RG, Whitear S-L, Sreenan JM. 2008. Female reproductive tract fluids: composition, mechanism of formation and potential role in the developmental origins of health and disease. Reprod Fertil Dev, 20:1-8.

Lefebvre R, Suarez SS. 1996. Effect of capacitation on bull sperm binding to homologous oviductal epithelium. Biol Reprod, 54:575-582. 
Lefebvre R, Lo MC, Suarez SS. 1997. Bovine sperm binding to oviductal epithelium involves fucose recognition. Biol Reprod, 56:1198-1204.

Levanon K, Ng V, Piao H-Y, Zhang Y, Chang MC, Roh MH, Kindelberger DW, Hirsch MS, Crum CP, Marto JA, Drapkin RI. 2010. Primary ex-vivo cultures of human fallopian tube epithelium as a model for serous ovarian carcinogenesis. Oncogene, 29:1103-1113.

Lishko PV, Botchkina IL, Kirichok Y. 2011. Progesterone activates the principal $\mathrm{Ca} 2+$ channel of human sperm. Nature, 471:387-391.

Lonergan P, Rizos D, Kanka J, Nemcova L, Mbaye AM, Kingston M, Wade M, Duffy P, Boland MP. 2003. Temporal sensitivity of bovine embryos to culture environment after fertilization and the implications for blastocyst quality. Reproduction, 126:337-346.

Lonergan P, Fair T. 2008. In vitro-produced bovine embryos: dealing with the warts. Theriogenology, 69:17-22.

Lonergan P, Forde N, Spencer T. 2016. Role of progesterone in embryo development in cattle. Reprod Fertil Dev, 28:66-74.

Lopera-Vásquez R, Hamdi M, Fernandez-Fuertes B, Maillo V, Beltrán-Breña $P$, Calle $A$, Redruello A, López-Martín S, Gutierrez-Adán A, Yañez-Mó M, Ramirez MÁ, Rizos D. 2016. Extracellular vesicles from BOEC in in vitro embryo development and quality. PloS One, 11:e0148083.

Lopera-Vasquez R, Hamdi M, Maillo V, GutierrezAdan A, Bermejo-Alvarez P, Ramírez MÁ, YáñezMó M, Rizos D. 2017. Effect of bovine oviductal extracellular vesicles on embryo development and quality in vitro. Reproduction, 153:461-470.

Lyons RA, Saridogan E, Djahanbakhch O. 2006. The effect of ovarian follicular fluid and peritoneal fluid on Fallopian tube ciliary beat frequency. Hum Reprod, 21:52-56.

Mahi-Brown CA, Yanagimachi R. 1983. Parameters influencing ovum pickup by oviductal fimbria in the golden hamster. Gamete Res, 8:1-10.

Maillo V, Rizos D, Besenfelder U, Havlicek V, Kelly AK, Garrett M, Lonergan P. 2012. Influence of lactation on metabolic characteristics and embryo development in postpartum Holstein dairy cows. $J$ Dairy Sci, 95:3865-3876.

Maillo V, Gaora PÓ, Forde N, Besenfelder U, Havlicek V, Burns GW, Spencer TE, GutierrezAdan A, Lonergan P, Rizos D. 2015. Oviduct-embryo interactions in cattle: two-way traffic or a one-way street? Biol Reprod, 92:144. doi 10.1095/biolreprod.115.127969. ex2015a, 2015b

Maillo V, Sánchez-Calabuig MJ, Lopera-Vasquez R, Hamdi M, Gutierrez-Adan A, Lonergan P, Rizos D. 2016. Oviductal response to gametes and early embryos in mammals. Reproduction, 152:R127-141.

Marey MA, Liu J, Kowsar R, Haneda S, Matsui M, Sasaki M, Takashi S, Hayakawa $H$, Wijayagunawardane MPB, Hussein FM, Miyamoto A. 2014. Bovine oviduct epithelial cells downregulate phagocytosis of sperm by neutrophils: prostaglandin E2 as a major physiological regulator. Reproduction, $147: 211-219$
McComb P, Langley L, Villalon M, Verdugo P. 1986. The oviductal cilia and Kartagener's syndrome. Fertil Steril, 46:412-416.

Miessen K, Sharbati S, Einspanier R, Schoen J. 2011. Modelling the porcine oviduct epithelium: a polarized in vitro system suitable for long-term cultivation. Theriogenology, 76:900-910.

Miki K, Clapham DE. 2013. Rheotaxis guides mammalian sperm. Curr Biol, 23:443-452.

Ng YH, Rome S, Jalabert A, Forterre A, Singh H, Hincks CL, Salamonsen LA. 2013. Endometrial exosomes/microvesicles in the uterine microenvironment: a new paradigm for embryoendometrial cross talk at implantation. PloS One, 8:e58502. doi: 10.1371/journal.pone.0058502.

Nieder GL, Macon GR. 1987. Uterine and oviducal protein secretion during early pregnancy in the mouse. $J$ Reprod Fertil, 81:287-294.

O'Day-Bowman MB, Mavrogianis PA, Reuter LM, Johnson DE, Fazleabas AT, Verhage HG. 1996. Association of oviduct-specific glycoproteins with human and baboon (Papio anubis) ovarian oocytes and enhancement of human sperm binding to human hemizonae following in vitro incubation. Biol Reprod, 54:60-69.

Odhiambo JF, Poole DH, Hughes L, Dejarnette JM, Inskeep EK, Dailey RA. 2009. Pregnancy outcome in dairy and beef cattle after artificial insemination and treatment with seminal plasma or transforming growth factor beta-1. Theriogenology, 72:566-571.

Okada A, Ohta Y, Inoue S, Hiroi H, Muramatsu M, Iguchi T. 2003. Expression of estrogen, progesterone and androgen receptors in the oviduct of developing, cycling and pre-implantation rats. $J$ Mol Endocrinol, 30:301-315.

Okunade GW, Miller ML, Pyne GJ, Sutliff RL, O'Connor KT, Neumann JC, Andringa A, Miller DA, Prasad V, Doetschman T, Paul RJ, Shull GE. 2004. Targeted ablation of plasma membrane Ca2+ATPase (PMCA 1 and 4 indicates a major housekeeping function for PMCA1 and a critical role in hyperactivated sperm motility and male fertility for PMCA4. J Biol Chem, 279:33742-33750.

Olds D, VanDemark NL. 1957. The behaviour of spermatozoa in the luminal fluids of bovine female genitalia. Am J Vet Res, 18:603-607.

Oliphant G, Bowling A, Eng LA, Keen S, Randall PA. 1978. The permeability of rabbit oviduct to proteins present in the serum. Biol Reprod, 18:516-520.

Orihuela PA, Zuñiga LM, Rios M, ParadaBustamante A, Sierralta WD, Velásquez LA, Croxatto HB. 2009. Mating changes the subcellular distribution and the functionality of estrogen receptors in the rat oviduct. Reprod Biol Endocrinol, 7:139. doi: 10.1186/1477-7827-7-139.

Parrish JJ, Susko-Parrish JL, Handrow RR, Sims MM, FirstNL. 1989. Capacitation of bovine spermatozoa by oviduct fluid. Biol Reprod, 40:10201025.

Pérez-Cerezales S, Boryshpolets S, Afanzar O, Brandis A, Nevo R, Kiss V, Eisenbach M. 2015a. Involvement of opsins in mammalian sperm 
thermotaxis. Sci Rep, 5. doi:10.1038/srep16146.

Pérez-Cerezales S, Boryshpolets S, Eisenbach $M$. 2015b. Behavioral mechanisms of mammalian sperm guidance. Asian J Androl, 17:628-632.

Pérez-Cerezales S, Ramos-Ibeas P, Acuña OS, Avilés M, Coy P, Rizos D, Gutiérrez-Adán A. 2018. The oviduct: from sperm selection to the epigenetic landscape of the embryo. Biol Reprod, 98:262-276.

Piehl LL, Fischman ML, Hellman U, Cisale H, Miranda PV. 2013. Boar seminal plasma exosomes: effect on sperm function and protein identification by sequencing. Theriogenology 79:1071-1082.

Pollard JW, Plante C, King WA, Hansen PJ, Betteridge KJ, Suarez SS. 1991. Fertilizing capacity of bovine sperm may be maintained by binding of oviductal epithelial cells. Biol Reprod, 44:102-107.

Quill TA, Sugden SA, Rossi KL, Doolittle LK, Hammer RE, Garbers DL. 2003. Hyperactivated sperm motility driven by CatSper2 is required for fertilization. Proc Natl Acad Sci, 100:14869-14874.

Quinn P, Kerin JF, Warnes GM. 1985. Improved pregnancy rate in human in vitro fertilization with the use of a medium based on the composition of human tubal fluid. Fertil Steril, 44:493-498.

Ramos-Ibeas P, Calle A, Pericuesta E, LagunaBarraza $\mathbf{R}$, Moros-Mora $\mathbf{R}$, Lopera-Vásquez $\mathbf{R}$, Maillo V, Yáñez-Mó M, Gutiérrez-Adán A, Rizos D, Ramírez MÁ. 2014. An efficient system to establish biopsy-derived trophoblastic cell lines from bovine embryos. Biol Reprod, 91:15 https://doi.org/10.1095/biolreprod.114.118430

Randi F, Fernandez-Fuertes, B, McDonald M, Forde N, Kelly AK, Bastos Amorin H, Muniz de Lima E, Morotti F, Marcondes Seneda M, Lonergan P. 2016. Asynchronous embryo transfer as a tool to understand embryo-uterine interaction in cattle: is a large conceptus a good thing? Reprod Fertil Dev, 28:1999-2006.

Raposo G, Stoorvogel W. 2013. Extracellular vesicles: exosomes, microvesicles, and friends. $J$ Cell Biol, 200:373-383

Ren D, Navarro B, Perez G, Jackson ACHsu S, ShiQ, TillyJL, Clapham DE. 2001. A sperm ion channel required for sperm motility and male fertility. Nature, 413:603-609.

Rizos D, Ward F, Duffy P, Boland MP, Lonergan P 2002. Consequences of bovine oocyte maturation, fertilization or early embryo development in vitro versus in vivo: implications for blastocyst yield and blastocyst quality. Mol Reprod Dev, 61:234-248.

Rizos D, Carter F, Besenfelder U, Havlicek V, Lonergan P. 2010. Contribution of the female reproductive tract to low fertility in postpartum lactating dairy cows. J Dairy Sci, 93:1022-1029.

Robertson SA, Guerin LR, Bromfield JJ, Branson KM, Ahlström AC, Care AS. 2009. Seminal fluid drives expansion of the $\mathrm{CD} 4+\mathrm{CD} 25+\mathrm{T}$ regulatory cell pool and induces tolerance to paternal alloantigens in mice. Biol Reprod, 80:1036-1045.

Rodríguez-Alonso B, Sánchez JM, Hamdi M, Havlicek V, Besenfelder U, Lonergan P, Rizos D. 2018a. Oviduct-embryo interaction in cattle: Effect of asynchrony between the embryo and the oviduct on subsequent embryo development. 34th Annual Meeting of ESHRE, 1-4 July 2018, Barcelona, Spain. (abstract).

Rodríguez-Alonso B, Hamdi M, Sánchez JM, Gutierrez-Adán A, Lonergan P, Rizos D. 2018b. 115 In vivo transcriptomic response of bovine oviduct epithelial cells to the early embryo. Reprod Fertil Dev, 30:197. (abstract)

Rottmayer R, Ulbrich SE, Kölle S, Prelle K, Neumueller C, Sinowatz F, Meyer HHD, Wolf E, Hiendleder S. 2006. A bovine oviduct epithelial cell suspension culture system suitable for studying embryomaternal interactions: morphological and functional characterization. Reprod, 132:637-648. https://doi.org/10.1530/rep.1.01136.

Saadeldin IM, Oh HJ, Lee BC. 2015. Embryonicmaternal cross-talk via exosomes: potential implications. Stem Cells Cloning, 8:103-107. SalilewWondim D, Fournier E, Hoelker M, Saeed-Zidane M, Tholen E, Looft C, Neuhoff C, Besenfelder U, Havlicek V, Rings F, Gagné D, Sirard MA, Robert C, Shojaei Saadi HA, Gad A, Schellander K, Tesfaye D. 2015. Genome-wide DNA methylation patterns of bovine blastocysts developed in vivo from embryos completed different stages of development in vitro. PLoS One, 10:e140467. doi: 10.1371/journal.pone. 0140467.

Schäfer-Somi S. 2003. Cytokines during early pregnancy of mammals: a review. Anim Reprod Sci, 75:73-94

Schmaltz-Panneau B, Cordova A, Dhorne-Pollet S, Hennequet-Antier C, Uzbekova S, Martinot E, Doret S, Martin P, Mermillod P, Locatelli Y. 2014. Early bovine embryos regulate oviduct epithelial cell gene expression during in vitro co-culture. Anim Reprod Sci, 149:103-116.

https://doi.org/10.1016/j.anireprosci.2014.06.022.

Shima T, Inada K, Nakashima A, Ushijima A, Ito M, Yoshino O, Saito S. 2015. Paternal antigen-specific proliferating regulatory $\mathrm{T}$ cells are increased in uterinedraining lymph nodes just before implantation and in pregnant uterus just after implantation by seminal plasma-priming in allogeneic mouse pregnancy. $J$ Reprod Immunol, 108:72-82.

Silveira JC, Veeramachaneni DNR, Winger QA, Carnevale EM, Bouma GJ. 2012. Cell-secreted vesicles in equine ovarian follicular fluid contain mirnas and proteins: a possible new form of cell communication within the ovarian follicle. Biol Reprod, 86:71. doi: 10.1095/biolreprod.111.093252.

Simintiras CA, Forde N. 2017. Understanding the uterine environment in early pregnancy in cattle: How have the omics enhanced our knowledge? Anim Reprod, 14:538-546.

Simintiras CA, Sturmey RG. 2017. Genistein crosses the bioartificial oviduct and alters secretion composition. Reprod Toxicol, 71:63-70.

Simintiras CA, Fröhlich T, Sathyapalan T, Arnold GJ, Ulbrich SE, Leese HJ, Sturmey RG. 2017. Modelling aspects of oviduct fluid formation in vitro. Reproduction, 153:23-33.

Simpson RJ, Jensen SS, Lim JWE. 2008. Proteomic profiling of exosomes: current perspectives. Proteomics, 
8:4083-4099.

Smith JF, Syritsyna O, Fellous M, Serres C, Mannowetz N, Kirichok Y, Lishko PV. 2013. Disruption of the principal, progesterone-activated sperm $\mathrm{Ca} 2+$ channel in a CatSper2-deficient infertile patient. Proc Natl Acad Sci, 110:6823-6828.

Smits K, De Coninck DIM, Van Nieuwerburgh F, Govaere J, Van Poucke M, Peelman L, Deforce D, Van Soom A. 2016. The equine embryo influences immune-related gene expression in the oviduct. Biol Reprod, 94:36. doi: 10.1095/biolreprod.115.136432.

Steffl M, Schweiger M, Sugiyama T, Amselgruber WM. 2008. Review of apoptotic and non-apoptotic events in non-ciliated cells of the mammalian oviduct. Ann Anat, 190:46-52.

Suarez SS. 2006. Interactions of spermatozoa with the female reproductive tract: inspiration for assisted reproduction. Reprod Fertil Dev, 19:103-110.

Thery C. 2011. Exosomes: secreted vesicles and intercellular communications. F1000 Biol Rep, 3. doi: 10.3410/B3-15.

Thibodeaux JK, Menezo Y, Roussel JD, Hansel W, Goodeaux LL, Thompson DL, Godke RA. 1992. Coculture of in vitro fertilized bovine embryos with oviductal epithelial cells originating from different stages of the estrous cycle. J Dairy Sci, 75:1448-1455. https://doi.org/10.3168/jds.S0022-0302(92)77900-4

Töpfer-Petersen E, Wagner A, Friedrich J, Petrunkina A, Ekhlasi-Hundrieser M, Waberski D, Drommer W. 2002. Function of the mammalian oviductal sperm reservoir. J Exp Zool, 292:210-215.

Tung C, Hu L, Fiore AG, Ardon F, Hickman DG, Gilbert RO, Suarez SS, Wu M. 2015. Microgrooves and fluid flows provide preferential passageways for sperm over pathogen Tritrichomonas foetus. Proc Natl Acad Sci, 112:5431-5436.

Ulbrich SE, Zitta K, Hiendleder S, Wolf E. 2010. In vitro systems for intercepting early embryo-maternal cross-talk in the bovine oviduct. Theriogenology, 73:802-816
Verhage HG, Fazleabas AT, Jaffe RC, Murray MK. 1988. Estrogen-dependent synthesis and release of a protein (CUPED by cultured uterine explants from the domestic cat. Theriogenology, 30:469-476.

Visconti PE, Westbrook VA, Chertihin O, Demarco I, Sleight S, Diekman AB. 2002. Novel signaling pathways involved in sperm acquisition of fertilizing capacity. J Reprod Immunol, 53:133-150.

Walter I. 1995. Culture of bovine oviduct epithelial cells (BOEC). Anat Rec, 243:347-356.

Wetscher F, Havlicek V, Huber T, Müller M, Brem G, Besenfelder U. 2005. Effect of morphological properties of transferred embryonic stages on tubal migration: implications for in vivo culture in the bovine oviduct. Theriogenology, 64:41-48.

Wijayagunawardane MP, Miyamoto A, Cerbito WA, Acosta TJ, Takagi M, Sato K. 1998. Local distributions of oviductal estradiol, progesterone, prostaglandins, oxytocin and endothelin- 1 in the cyclic cow. Theriogenology, 49:607-618.

Xia J, Ren D. 2009a. Egg coat proteins activate calcium entry into mouse sperm via CATSPER channels. Biol Reprod, 80:1092-1098. ex2009b

Xia J, Ren D. 2009b. The BSA-induced $\mathrm{Ca}(2+$ influx during sperm capacitation is CATSPER channeldependent. Reprod Biol Endocrinol, 7:119. doi: 10.1186/1477-7827-7-119. ex2009a

Yanagimachi R. 1994. Mammalian fertilization. Physiol Reprod, 1:189-317.

Yániz JL, Lopez-Gatius F, Santolaria P, Mullins KJ. 2000. Study of the functional anatomy of bovine oviductal mucosa. Anat Rec, 260:268-278.

Yousef MS, Marey MA, Hambruch N, Hayakawa H, Shimizu T, Hussien HA, Abdel-Razek A-RK, Pfarrer C, Miyamoto A. 2016. Sperm binding to oviduct epithelial cells enhances TGFB1 and IL10 expressions in epithelial cells as well as neutrophils in vitro: prostaglandin E2 as a main regulator of antiinflammatory response in the bovine oviduct. PloS One, 11:e0162309. 